\title{
Saline-sodic soil and organic matter addition in the cultivation of the colored cotton 'BRS Topázio'
}

\author{
Solo salino sódico e adição de matéria orgânica no cultivo do \\ algodoeiro colorido 'BRS Topázio'
}

\author{
Magaly Morgana Lopes da $\operatorname{Costa}^{1}$; Reginaldo Gomes Nobre ${ }^{2 *}$ \\ Geovani Soares de Lima ${ }^{3}$; Hans Raj Gheyi ${ }^{4}$; Francisco Wesley Alves Pinheiro${ }^{1}$; \\ Adaan Sudário Dias ${ }^{1}$; Lauriane Almeida dos Anjos Soares ${ }^{5}$
}

\begin{abstract}
The prevailing climate of the semiarid region in the northeastern region of Brazil along with inadequate irrigation management, have caused the formation of halomorphic soils, which have hampered agricultural production and environmental sustainability of this region. Therefore, this study aimed to evaluate the emergence and initial growth of the cotton cultivar 'BRS Topázio' cultivated in soil with different levels of exchangeable sodium percentage (ESP) and concentrations of organic matter (OM) in a greenhouse from April to June 2014. The experiment was set in a randomized block design in a 5 $\times 4$ factorial scheme, with three replicates, and the treatments consisted of five ESP levels (13.6, 22.4, $30.1,39.0$, and 48.0$)$ and four OM concentrations $(0,5,10$, and $15 \%$ based on soil volume). Soils with an ESP ranging from 13.6 to 48.0 did not interfere with the emergence and number of leaves of cotton at 10 days after seeding (DAS). At 44 DAS, in the period preceding the flowering stage, ESPs ranging from 27 to 30 promoted greater plant height, stem diameter, and fresh and dry matter of shoot. Increasing OM increased the emergence percentage and emergence speed index and, at 44 DAS, increased plant height, stem diameter, and shoot fresh and dry matter. Increasing OM mitigated the effect of the exchangeable sodium up to an ESP of 30 on the number of leaves, plant height, stem diameter, and leaf area at 10 DAS, and up to mean ESPs of 28.5 and 34.0 for the number of leaves and leaf area, respectively, at 44 DAS.

Key words: Gossypium hirsutum L. Sodicity. Cattle manure.
\end{abstract}

\section{Resumo}

As condições de clima prevalecentes na região semiárida do nordeste Brasileiro, associado ao manejo inadequado da irrigação tem ocasionado a formação de solos halomórficos, promovendo assim, impactos negativos sobre a produção agrícola e a sustentabilidade ambiental desta região. Deste modo, objetivouse com este trabalho avaliar a emergência e o crescimento inicial do algodoeiro cv. BRS Topázio

\footnotetext{
${ }^{1}$ Discentes do Curso de Graduação em Agronomia, Universidade Federal de Campina Grande, UFCG, Centro de Ciências e Tecnologia Agroalimentar, Pombal, PB, Brasil. E-mail: magaly_morgana@hotmail.com; wesley.ce@hotmail.com; sudario_ dias@hotmail.com

2 Prof., Unidade Acadêmica de Ciências Agrárias, UFCG, Centro de Ciências e Tecnologia Agroalimentar, Pombal, PB, Brasil. E-mail: rgomesnobre@yahoo.com.br

${ }^{3}$ Bolsista do Programa Nacional de Pós-Doutorado, PNPD/CAPES, UFCG, Centro de Tecnologia e Recursos Naturais, Campina Grande, PB, Brasil. E-mail: geovanisoareslima@gmail.com

${ }^{4}$ Prof. Visitante Nacional Sênior, CAPES, Universidade Federal do Recôncavo da Bahia, UFRB, Cruz das Almas, BA, Brasil. E-mail: hans@pq.cnpq.br

5 Discente do Curso de Doutorado do Programa de Pós-Graduação em Enga Agrícola, UFCG, Centro de Tecnologia e Recursos Naturais Campina Grande, PB, Brasil. E-mail: laurispo.agronomia@gmail.com

* Author for correspondence
} 
cultivado em um solo com diferentes percentagens de sódio trocável e doses de matéria orgânica, em pesquisa conduzida em casa de vegetação entre abril e junho de 2014. Utilizou-se o delineamento de blocos ao acaso, em esquema fatorial 5 x 4, com 3 repetições, sendo estudados cinco percentagens de sódio trocáveis $(13,6 ; 22,4 ; 30,1 ; 39,0$ e 48,0$)$ e quatro doses de matéria orgânica $(0 ; 5 ; 10$ e $15 \%$ em base do volume do solo). Solos com percentagem de sódio trocável variando de 13,6 a 48,0 não interferem na emergência nem no número de folhas do algodoeiro aos 10 dias após a semeadura. Aos 44 dias após o a semeadura, período que antecede a floração, a percentagem de sódio trocável variando de 27 a 30 promoveu maior altura de planta, diâmetro de caule e a fitomassa fresca e seca da parte aérea. Enquanto as doses crescentes de matéria orgânica proporcionam maior percentagem de emergência e índice de velocidade de emergência e, aos 44 dias após a semeadura a altura de planta, o diâmetro de caule e a fitomassa fresca e seca da parte aérea do algodoeiro. O incremento nas doses de matéria orgânica atenuaram o efeito do sódio trocável até a PST de 30 sobre o número de folhas, altura de planta, diâmetro de caule e a área foliar do algodoeiro aos 10 dias após a semeadura; e até a percentagem de sódio trocável média de 28,5 e 34,0 respectivamente, sobre o número de folhas e a área foliar aos 44 dias após a semeadura.

Palavras-chave: Gossypium hirsutum L. Sodicidade. Esterco bovino.

\section{Introduction}

Soils affected by soluble salts and/or exchangeable sodium are mostly located in arid and semiarid regions, where evaporation exceeds rainfall (MELO et al., 2008). These soils are found in more than 100 countries from all continents except Antarctica. In Brazil, this problem occurs mainly in the northeast region, where approximately $25 \%$ of irrigated areas have been salinized (GHEYI, 2000; LEAL et al., 2008).

In these areas, soils compromised by salinity and especially by sodicity have high $\mathrm{pH}$, excess salt in water, and a high exchangeable sodium percentage (ESP). From a physical-chemical perspective, these soils have limited capacity for infiltration and drainage, high micro porosity, and high water retention capacity (LEITE et al., 2007). Therefore, high salinity and ESP limit the productivity of these soils, which creates serious economic problems because they become inadequate for agriculture and are discarded from the production system (BARROS et al., 2005).

In the reclamation of the soils, the use of soil conditioners, like agricultural gypsum and organic residues (cattle manure), has been the most recommended practice. Many studies have been conducted on minimizing the impacts caused by excesses of soluble salts and exchangeable sodium in the soil. Vital et al. (2005), evaluating the application of four levels of gypsum $(0,50,100$, and $200 \%$ of the gypsum necessary) in a salinesodic soil, concluded that increasing gypsum lowered pH and ESP. Sousa et al. (2012) stated that the application of calcium sulfate, elemental sulfur, or sulfuric acid followed by washing decreased the salinity and sodicity of a saline-sodic soil.

Freire and Freire (2007) stated that the use of organic conditioners (cattle manure, rice husks, and vinasse) can also reduce ESP, possibly due to the release of $\mathrm{CO}_{2}$ and organic acids during the decomposition of organic matter (OM), besides acting as sources of calcium and magnesium, instead of sodium.

Because of these results, the growing need to improve agricultural production, and the high investments required by the conventional reclamation process, the use of organic matter (cattle manure) and the use of salt-tolerant species have emerged as low-cost alternatives for the recovery of salt-affected soils.

In this context, the cotton crop stands out for its salt tolerance, since it is able to express its maximum productive potential at a threshold salinity value of $7.7 \mathrm{dS} \mathrm{m}^{-1}$ in the soil saturation extract (ECse) and $5.1 \mathrm{dS} \mathrm{m}^{-1}$ in irrigation water. Yield decreases of $10,25,50$, and $100 \%$ are expected when ECse 
is 9.6, 13.0, 17.0, and $27.0 \mathrm{dS} \mathrm{m}^{-1}$ (DOORENBOS; KASSAM, 1994). Although it is considered to be a tolerant crop, scarce information is found in the literature on the threshold levels of ESP and its effects on the colored cotton "BRS Topázio", developed by Embrapa Cotton. After the industrial processing of cotton bolls, $37-43 \%$ of its fiber and $57-63 \%$ of seeds are obtained. The fiber is used in the textile industry, and the seeds are also industrially processed, generating 5.5\% lint, 15.2\% crude oil, $47.7 \%$ cake, $25.7 \%$ husk, and 5.9\% residue (BELTRÃO; AZEVEDO, 2008).

Given the above, this study aimed to evaluate the emergence and initial growth of the colored cotton cultivar"BRS Topázio"underdifferent exchangeable sodium percentages and concentrations of organic matter.

\section{Material and Methods}

The experiment was carried out from April to June 2014 in pots under greenhouse conditions at the Center for Sciences and Agrifood Technology of the Federal University of Campina Grande (CCTA/ UFCG), in the municipality of Pombal, PB, Brazil (6²8'16" S; 3749'15" W; 144 m).

A completely randomized block design was used and the treatments were distributed in a $5 \times$ 4 factorial scheme, with three replicates, consisting of five ESP levels $\left(\mathrm{P}_{1}-13.6, \mathrm{P}_{2}-22.4, \mathrm{P}_{3}-30.1, \mathrm{P}_{4}\right.$ 39.0 , and $\left.\mathrm{P}_{5}-48.0\right)$ and four OM concentrations ( 0 , 5,10 , and $15 \%$ based on soil volume), totaling 60 experimental units.

For the experiment, 12-L pots were filled with $1.0 \mathrm{~kg}$ of crushed stone ( $\mathrm{n}^{\mathrm{o}}$ zero), followed by 1.0 $\mathrm{kg}$ of sand to facilitate drainage. Later, $12 \mathrm{~kg}$ of clod-free material from a sodic soil, according to the treatment, was added. The soil material was collected in an area of the swine sector of the São Gonçalo Irrigation District, $10 \mathrm{~km}$ away from the municipality of Sousa, PB, and the physicochemical characteristics (Table 1) were determined in the Laboratory of Soils and Plant Nutrition of the CCTA/UFCG, according to the methodology proposed by Claessen (1997). The pots had holes at the bottom for monitoring the drained volume and water consumption by plant.

Table 1. Physico-chemical characteristics of the soil used in the experiment, before applying the treatments.

\begin{tabular}{|c|c|c|c|c|c|c|c|c|c|c|c|}
\hline \multirow{2}{*}{ Density } & \multirow{2}{*}{$\begin{array}{c}\text { Total } \\
\text { porosity }\end{array}$} & \multirow{2}{*}{ Sand } & \multirow{2}{*}{ Silt } & \multirow{2}{*}{ Clay } & \multicolumn{4}{|c|}{ Exchange Complex } & \multirow{2}{*}{ ESP } & \multirow{2}{*}{$\mathrm{pH}_{\mathrm{sp}}$} & \multirow{2}{*}{$\mathrm{EC}_{\mathrm{se}}$} \\
\hline & & & & & $\mathrm{Ca}^{2+}$ & $\mathrm{Mg}^{2+}$ & $\mathrm{Na}^{+}$ & $\mathrm{K}^{+}$ & & & \\
\hline $\mathrm{kg} \mathrm{dm}^{-3}$ & $\mathrm{~m}^{3} \mathrm{~m}^{-3}$ & ............ & $\ldots \mathrm{g} \mathrm{kg}^{-1}$ & $\cdots$ & & ....cmo & & & $\%$ & - & $\mathrm{dS} \mathrm{m}^{-1}$ \\
\hline 1.32 & 0.52 & 729 & 131 & 140 & 1.74 & 0.42 & 25.44 & 0.71 & 89.95 & 9.62 & 45.20 \\
\hline
\end{tabular}

$\mathrm{Ca}^{2+}$ and $\mathrm{Mg}^{2+}$ extracted with $1 \mathrm{~mol} \mathrm{~L}{ }^{-1} \mathrm{KCl}$ at $\mathrm{pH} 7.0 ; \mathrm{Na}^{+}$and $\mathrm{K}^{+}$extracted with $1 \mathrm{~mol} \mathrm{~L}^{-1} \mathrm{NH}_{4} \mathrm{OAc}$ at $\mathrm{pH} 7.0$; ESP - exchangeable sodium percentage; $\mathrm{pH}_{\mathrm{sp}}-\mathrm{pH}$ of the saturation paste; $\mathrm{EC}_{\mathrm{se}}-$ electrical conductivity in the saturation extract.

Soil samples with different ESP levels were obtained from the previously described saline-sodic soil, which was treated with different amounts of gypsum, based on the desired ESP level (15, 20, 30, 40 , and $45 \%$ ), according to Pizzarro (1978), as in Eq. 1:

$\mathrm{Dg}=((\mathrm{ESPi}-\mathrm{ESPf}) \times \mathrm{CEC} \times \mathrm{ew} \times \mathrm{h} \times \mathrm{ds}) / 100$ where,

Dg: theoretical amount of the corrective, $\mathrm{kg} \mathrm{ha}^{-1}$;

ESPi: initial exchangeable sodium percentage, \%;

ESPf: final exchangeable sodium percentage (desired), \%;

CEC: cation exchange capacity of the soil; 
ew: equivalent weight of the element or compound used as a corrective;

$\mathrm{h}$ : depth of the soil to be reclaimed $(\mathrm{cm})$; and ds: soil bulk density, $\mathrm{kg} \mathrm{dm}^{-3}$.

After gypsum was incorporated, the mixture was placed in 200-L containers and kept for 45 days with water content above field capacity in order to accelerate the solubilization of gypsum and the substitution of sodium from the exchange complex by calcium and its leaching with the washing (GHEYI, 2000). Leaching was performed continuously and the applied water depth (electrical conductivity $<0.23 \mathrm{dSm}^{-1}$ ) was equivalent to twice the total soil porosity.

At the end of the leaching period, the soil was air-dried, its clods were broken up, and it was sieved (2-mm grid); then, the samples were taken to the Laboratory of Soils and Plant Nutrition of the CCTA/UFCG for chemical characterization and determination of exchangeable sodium (Table 2). The results indicated soil ESPs of 13.6, 22.4, 30.1, 39.0, and 48.0 and ECse of 0.96, 1.42, 11.66, 8.12 , and $9.43 \mathrm{dS} \mathrm{m}^{-1}$, respectively. The cattle manure, used as a source of organic matter, was well decomposed and incorporated into the soil at concentrations of $0,5,10$, and $15 \%$ based on soil volume.

Table 2. Chemical characteristics of the soil used in the experiment, after applying the treatments.

\begin{tabular}{|c|c|c|c|c|c|c|c|c|}
\hline \multirow{2}{*}{$\begin{array}{l}\text { Exchangeable sodium } \\
\text { percentage }\end{array}$} & \multirow{2}{*}{$\mathrm{pH}_{\mathrm{sp}}$} & $\mathrm{K}^{+}$ & $\mathrm{Na}^{+}$ & $\mathrm{Ca}^{+2}$ & $\mathrm{Mg}^{+2}$ & $\mathrm{H}+\mathrm{Al}^{+3}$ & CEC & \multirow{2}{*}{$\begin{array}{l}\mathrm{EC}_{\mathrm{se}} \\
\mathrm{dS} \mathrm{\textrm {m } ^ { - 1 }}\end{array}$} \\
\hline & & & & $\ldots \ldots \ldots .$. & $\mathrm{kg}^{-1} \ldots$. & & & \\
\hline 13.6 & 8.43 & 0.41 & 1.70 & 9.91 & 0.42 & 0.00 & 12.44 & 0.96 \\
\hline 22.4 & 8.50 & 0.45 & 2.73 & 7.71 & 1.25 & 0.00 & 12.14 & 1.42 \\
\hline 30.1 & 8.88 & 0.23 & 4.39 & 9.35 & 0.57 & 0.00 & 14.54 & 11.66 \\
\hline 39.0 & 10.72 & 0.20 & 4.90 & 6.80 & 0.65 & 0.00 & 12.55 & 8.12 \\
\hline 48.0 & 10.77 & 0.17 & 6.15 & 5.90 & 0.59 & 0.00 & 12.81 & 9.43 \\
\hline
\end{tabular}

$\mathrm{Ca}^{2+}$ and $\mathrm{Mg}^{2+}$ extracted with $1 \mathrm{~mol} \mathrm{~L}{ }^{-1} \mathrm{KCl}$ at $\mathrm{pH} 7.0 ; \mathrm{Na}^{+}$and $\mathrm{K}^{+}$extracted with $1 \mathrm{~mol} \mathrm{~L}^{-1} \mathrm{NH}_{4} \mathrm{OAc}$ at $\mathrm{pH} 7.0$; ESP - exchangeable sodium percentage; $\mathrm{pH}_{\mathrm{sp}}--\mathrm{pH}$ of the saturation paste; $\mathrm{CEC}$-cation exchange capacity (sum of exchangeable cations); $\mathrm{EC}_{\mathrm{se}}-$ electrical conductivity of the saturation extract.

Seeding was performed using eight seeds per pot at $0.02 \mathrm{~m}$ depth, distributed equidistantly. After seeding, the soil was kept at field capacity with daily irrigation, and the applied water volume was calculated through the water balance in the root zone by subtracting the volume drained in the previous irrigation from the volume applied.

Seedling emergence started on the fourth day after seeding (DAS) and continued until the ninth day. At 21, 32, and 44 DAS, thinning was performed, leaving one plant, the most vigorous, per pot.

Fertilization with $\mathrm{N}$ and $\mathrm{K}_{2} \mathrm{O}(100$ and $150 \mathrm{mg}$ $\mathrm{kg}^{-1}$ ) was performed according to the recommendations of Novais et al. (1991); 1/3 as basal dose and $2 / 3$ divided into three equal applications through irrigation water, using urea and potassium chloride as the sources, respectively, in intervals of eight days, starting on 25 DAS. $\mathrm{P}_{2} \mathrm{O}_{5}$ (300 $\mathrm{mg} \mathrm{kg}^{-1}$ ) was applied only as basal fertilization, using single superphosphate.

Phytosanitary management consisted of manual removal of weeds performed weekly, and superficial scarification of the soil and staking after plants reached the flowering stage. In addition, an insecticide from the organophosphate group (1.5 $\mathrm{mL} \mathrm{L} \mathrm{L}^{-1}$ ) was used for the control of whiteflies and red spider mites. 
Seedling emergence was evaluated by monitoring the number of emerged seedlings daily until 9 DAS, adopting the appearance of the epicotyl on the soil surfaceas the criterion. Then, the emergence percentage (EP; number of germinated seedlings in relation to the number of seeds planted) was calculated. At 9 DAS, the emergence speed index (ESI) was calculated following the methodology described by Vieira and Carvalho (1994), according to Eq. 2:

$$
\text { ESI (seedlings day } \left.{ }^{-1}\right)=\frac{\sum_{1}}{N_{1}}+\frac{\sum_{2}}{N_{2}}+\cdots+\frac{\sum_{n}}{N_{n}}
$$

where:

$\Sigma_{1}, \Sigma_{2}, \ldots \Sigma_{\mathrm{n}}$ represent the number of emerged seedlings in the first, second, and last counts; and

$\mathrm{N}_{1}, \mathrm{~N}_{2}, \ldots \mathrm{N}_{\mathrm{n}}$ are the number of days from the seeding to the first, second, and last counts, respectively.

The growth of the cotton cultivar 'BRS Topázio' was evaluated at 10 and 44 DAS through the determination of the number of leaves (NL), plant height $(\mathrm{PH})$, stem diameter (SD), and leaf area (LA). Shoot fresh matter (SFM) and shoot dry matter (SDM) were evaluated at $44 \mathrm{DAS}$, in the period of pre-flowering and/or flowering. For the quantification of NL, only leaves with at least 50\% of photosynthetically active area and minimum length of $2 \mathrm{~cm}$ were considered. Plant height was defined as the distance from the plant base to the apical meristem. Stem diameter was measured $5 \mathrm{~cm}$ above the plant base and the leaf area was obtained according to the methodology of Grimes et al. (1969), as in Eq. 3:

$$
\mathrm{Y}=\Sigma 0.4322 x^{2.3002}
$$

For the evaluation of shoot fresh matter, plants collected at 44 DAS were separated into different parts (leaves and stems), put in paper bags, and weighed using a precision scale $(0.01 \mathrm{~g})$. Then, the material was dried in a forced-air oven at $65^{\circ} \mathrm{C}$ until constant weight, and the shoot fresh matter was determined.

The data were subjected to analysis of variance by F test and, when significant, analyses of linear and quadratic polynomial regression were performed. All the analyses were performed using the software SISVAR (FERREIRA, 2003). The choice of the regression was made through the best adjustment based on the coefficient of determination $\left(\mathrm{R}^{2}\right)$ and considering a probable biological explanation for the studied treatments.

\section{Results and Discussion}

According to the results of the analysis of variance (Table 3 ), the $\mathrm{OM}$ concentration had a significant effect $(\mathrm{p}<0.05)$ on the emergence percentage (EP) and emergence speed index (ESI). However, ESP levels and the ESP $\times$ OM interaction had no significant effects ( $p>0.05)$ on EP or ESI.

Seeds are usually sensitive to salinity effects and, when planted in saline solutions, there is an initial decrease in water absorption (MUNNS et al., 2006). However, in this study, there was no effect of soils with different ESP levels on plant emergence, which indicates the tolerance of the species to exchangeable sodium in this development stage. In addition, the substrates containing cattle manure possibly mitigate the effects of salts, stimulating seed osmotic adjustment, or this agricultural input may favor the reallocation of reserves from the cotyledons to the other organs, reducing the adverse effects of salinity on the emergence of seedlings (CAMPOS et al., 2009).

where:

$\mathrm{Y}=$ leaf area $\left(\mathrm{cm}^{2}\right)$,

$x=$ length of the leaf midrib $(\mathrm{cm})$. 
Table 3. Summary of the analysis of variance for the emergence percentage (EP) and emergence speed index (ESI) of the cotton cultivar 'BRS Topázio' cultivated in soil with different levels of exchangeable sodium percentage (ESP) and concentrations of organic matter $(\mathrm{OM})$.

\begin{tabular}{lccc}
\hline \multirow{2}{*}{ Sources of variation } & \multirow{2}{*}{ DF } & \multicolumn{2}{c}{ Mean Square } \\
\cline { 3 - 4 } & & EP & ESI \\
\hline Exchangeable sodium percentage (ESP) & 4 & $55.46^{\mathrm{ns}}$ & $0.001^{\text {ns }}$ \\
Organic matter $(\mathrm{OM})$ & 3 & $709.48^{*}$ & $0.006^{*}$ \\
$\quad$ Linear Regression & 1 & $2056.70^{* *}$ & $0.010^{*}$ \\
Quadratic Regression & 1 & $71.50^{\text {ns }}$ & $0.04^{\text {ns }}$ \\
Interaction $(\mathrm{ESP} \times \mathrm{OM})$ & 11 & $262.59^{\mathrm{ns}}$ & $0.002^{\mathrm{ns}}$ \\
Blocks & 2 & $182.80^{\mathrm{ns}}$ & $0.005^{\text {ns }}$ \\
CV $(\%)$ & & 21.68 & 28.00 \\
\hline
\end{tabular}

$\mathrm{ns},{ }^{* *}$, and $*$ indicate, respectively, non-significant, significant at $\mathrm{p}<0.01$, and $\mathrm{p}<0.05$;DF -degrees of freedom; CV -coefficient of variation.

Cotton EP and ESI showed positive linear correlations with increasing OM, with an increment of about $1.8 \%$ in EP (Figure 1A) and $1.3 \%$ in ESI (Figure 1B) per unit increase in OM, i.e., the $15 \%$ OM treatment increased EP by $27.0 \%$ and ESI by $19.7 \%$ compared to the $0 \%$ OM treatment.

The application of organic materials, besides improving soil structure, reduces the formation of crusts on the soil surface, which leads to a higher infiltration rate and respiration, thus increasing the emergence and growth of seedlings (SILVA et al., 2008). However, Santos et al. (2005), in a study with sodic soil treated with 0 and $20 \mathrm{t} \mathrm{ha}^{-1}$ of organic material (urban garbage compound), did not observe a significant effect on EP of the herbaceous cotton cultivar CNPA-7H, indicating that the type of organic matter and/or genotypes from the same species may have different behaviors.

Figure 1. Emergence percentage (EP; A) and emergence speed index (ESI; B) of the cotton cultivar 'BRS Topázio' as a function of the concentration of organic matter $(\mathrm{OM})$.
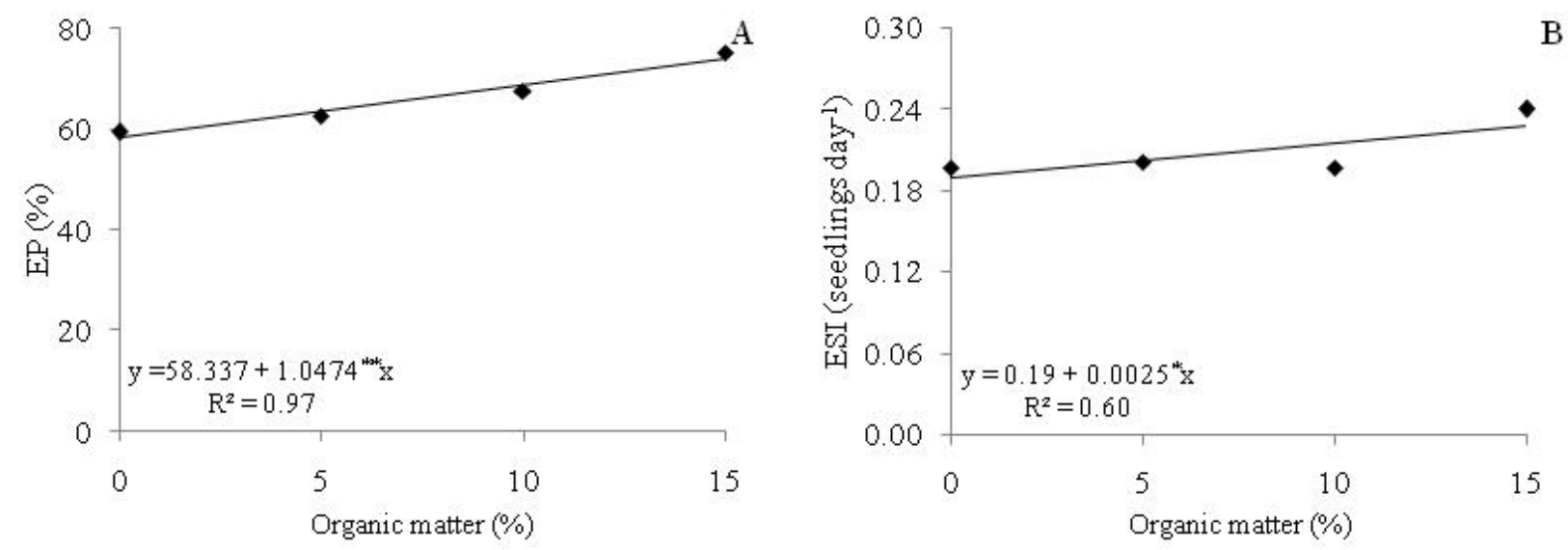
According to the results of the analysis of variance (Table 4), there was a significant effect of the different ESP levels on the number of leaves and stem diameter only at 44 DAS, and on plant height at 10 and 44 DAS. As to the OM concentration, the absence of a significant effect was observed only for the number of leaves at 10 DAS. However, there was a significant effect in the interaction between both factors $(\mathrm{ESP} \times \mathrm{OM})$ on the number of leaves at $44 \mathrm{DAS}$, and plant height and stem diameter at 10 DAS.

Table 4. Summary of the analysis of variance for the number of leaves (NL), plant height (PH), and stem diameter (SD) at 10 and 44 days after seeding of cotton cultivated in soil with different levels of exchangeable sodium percentage (ESP) and concentrations of organic matter (OM).

\begin{tabular}{|c|c|c|c|c|c|c|c|}
\hline \multirow{3}{*}{ Sources of variation } & \multirow{3}{*}{$\mathrm{DF}$} & \multicolumn{6}{|c|}{ Mean Square } \\
\hline & & \multicolumn{2}{|c|}{ NL } & \multicolumn{2}{|c|}{ PH } & \multicolumn{2}{|c|}{ SD } \\
\hline & & 10 & 44 & 10 & 44 & 10 & 44 \\
\hline $\begin{array}{l}\text { Exchangeable sodium } \\
\text { percentage (ESP) }\end{array}$ & 4 & $0.00^{\mathrm{ns}}$ & $20.40^{*}$ & $7.85^{*}$ & $400.25^{*}$ & $0.008^{\text {ns }}$ & $1.81^{*}$ \\
\hline Linear Regression & 1 & $0.00^{\text {ns }}$ & $5.20^{\text {ns }}$ & $12.16^{*}$ & $552.55^{*}$ & $0.00004^{\mathrm{ns}}$ & $1.24^{* *}$ \\
\hline Quadratic Regression & 1 & $0.00^{\mathrm{ns}}$ & $53.72^{*}$ & $17.61^{*}$ & $786.50^{*}$ & $0.01^{\mathrm{ns}}$ & $4.66^{*}$ \\
\hline Organic matter (OM) & 3 & $0.00^{\mathrm{ns}}$ & $17.44^{*}$ & $4.21^{*}$ & $334.38^{*}$ & $0.10^{*}$ & $3.15^{*}$ \\
\hline Linear Regression & 1 & $0.00^{\mathrm{ns}}$ & $51.25^{*}$ & $8.03^{*}$ & $589.40^{*}$ & $0.31^{*}$ & $8.00^{*}$ \\
\hline Quadratic Regression & 1 & $0.00^{\text {ns }}$ & $0.00^{\text {ns }}$ & $0.66^{\text {ns }}$ & $155.20^{* *}$ & $0.001^{\text {ns }}$ & $0.72^{* *}$ \\
\hline Interaction $(\mathrm{ESP} \times \mathrm{OM})$ & 11 & $0.00^{\mathrm{ns}}$ & $5.33^{* *}$ & $1.40^{*}$ & $20.57^{\mathrm{ns}}$ & $0.06^{*}$ & $0.27^{\mathrm{ns}}$ \\
\hline Blocks & 2 & $0.00^{*}$ & $3.15^{\mathrm{ns}}$ & $1.84^{* *}$ & $47.51^{\mathrm{ns}}$ & $0.01^{\mathrm{ns}}$ & $0.05^{\mathrm{ns}}$ \\
\hline CV $(\%)$ & & 10.00 & 16.24 & 11.29 & 12.70 & 8.70 & 10.03 \\
\hline
\end{tabular}

$\mathrm{ns}, * *$, and $*$, indicate, respectively, non-significant, significant at $\mathrm{p}<0.01$, and $\mathrm{p}<0.05$; DF -degrees of freedom; CV - coefficient of variation.

The interaction ESP $\times$ OM (Table 4) had a significant effect $(p<0.01)$ on the number of leaves of cotton only at 44 DAS and, according to the regression equations (Figure 2), quadratic responses were observed for the OM concentrations of 0,5 , and $15 \%$, indicating that the highest NL values (10.7, 11.0, and 13.6) were obtained with ESP levels of 27, 30, and 29, respectively. Thus, in sodic soil, as the cattle manure supply increased, the NL also increased, which can be attributed to the $\mathrm{N}$ in the cattle manure and to its functions in plant metabolism, since it is in chlorophyll, nucleic acids, and proteins, besides being the activator of many enzymes. In addition, $\mathrm{N}$ participates in vital processes in the plants, such as protein synthesis, ionic absorption, photosynthesis, respiration, and cell multiplication and differentiation (MALAVOLTA, 2006). No significant effect was observed on plants receiving $10 \%$ cattle manure, which showed a mean NL of 10.5, regardless of the ESP level.
Plant height $(\mathrm{PH})$ was influenced by the interaction between factors $(\mathrm{ESP} \times \mathrm{OM})$ only at 10 DAS. According to the regression equations (Figure 3A), there was a quadratic response of $\mathrm{PH}$ when plants were subjected to OM concentrations of 5,10 , and $15 \%$, and the highest values (8.4, 6.7 , and $7.2 \mathrm{~cm}$ ) were obtained at ESP levels of 28,32 , and 28, respectively. Similarly to NL, PH increased when plants were cultivated under an ESP of 30, then decreased as ESP increased to 48. This confirms the results observed by Maas and Hoffman (1977), who claimed that cotton tolerates ESP levels from 40 to 60 . When plants did not receive OM $(0 \%)$, the response was linear, with a decrease of about $0.84 \%$ per unit increase of ESP. Thus, OM application in sodic soils is important because, as the cattle manure was applied, there was an increase in $\mathrm{PH}$, even under a mean ESP of 30. 
Figure 2. Number of leaves (NL) of the cotton cultivar 'BRS Topázio' as a function of the interaction between the exchangeable sodium percentage (ESP) and the concentration of organic matter at 44 days after seeding (DAS).

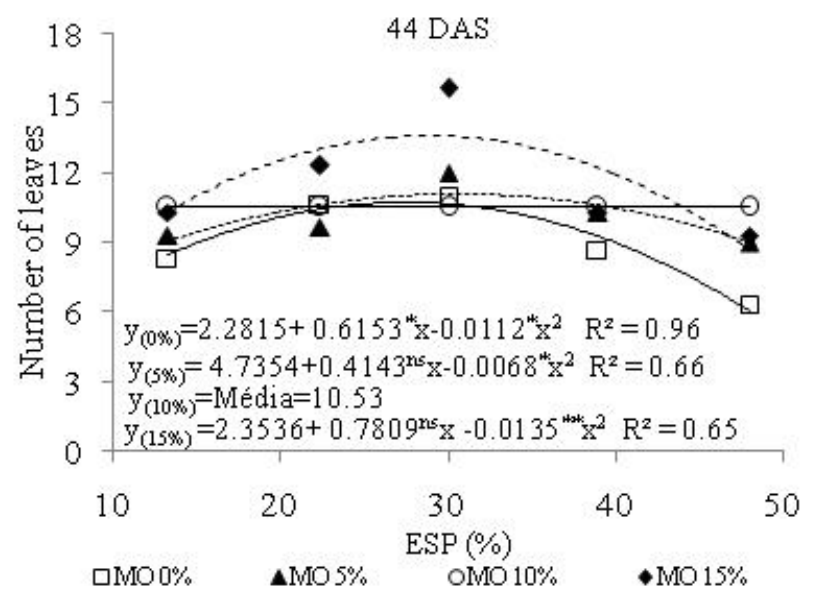

Figure 3. Plant height ( $\mathrm{PH})$ of the cotton cultivar 'BRS Topázio' as a function of the interaction between exchangeable sodium percentage (ESP) and the concentration of organic matter at 10 days after seeding (A), and as a function of ESP (B) and the concentration of organic matter at 44 DAS (C).

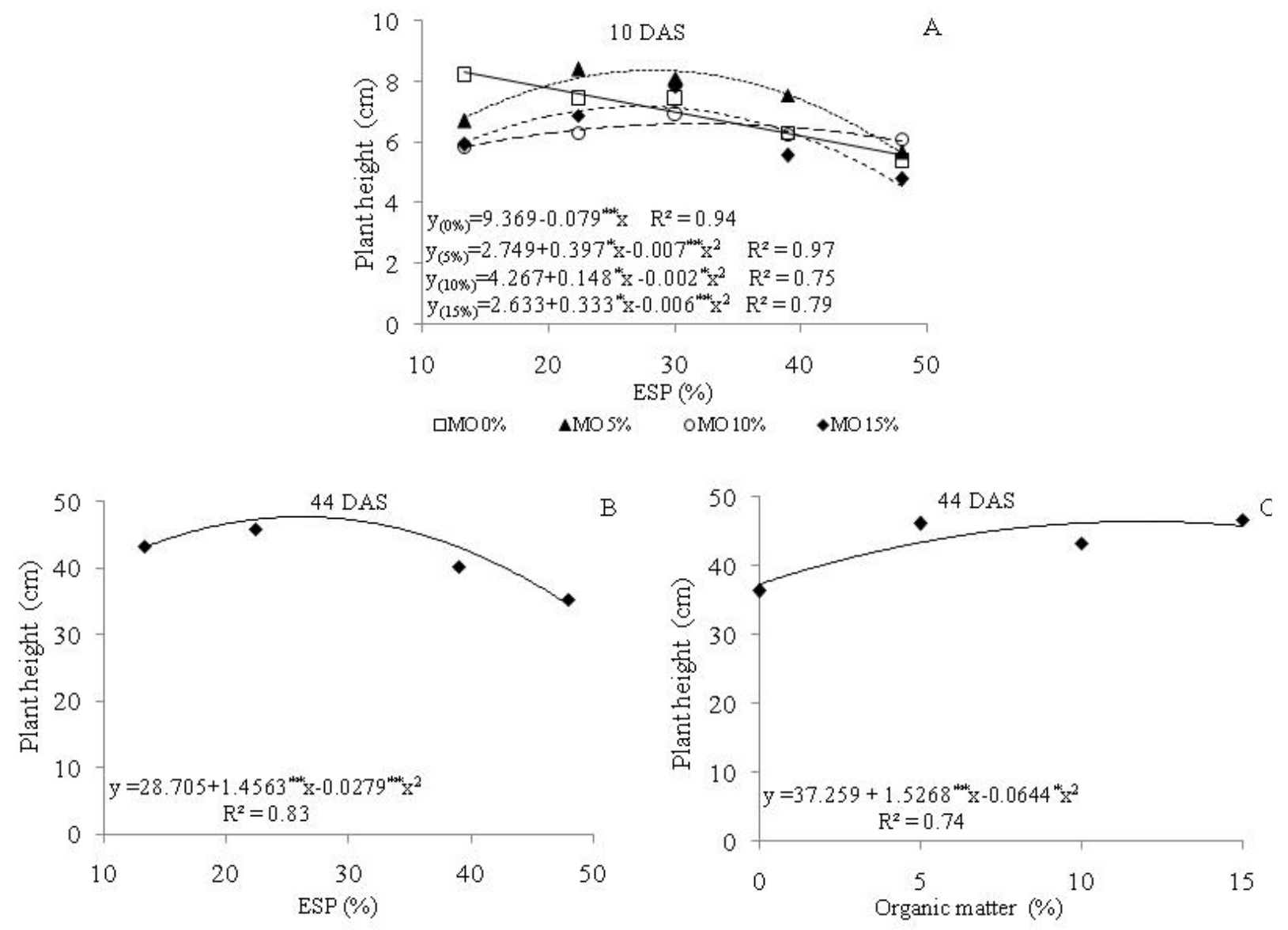


At 44 DAS, plant height was affected by the ESP levels $(\mathrm{p}<0.05)$ and, according to the regression equation (Figure 3B), there was a quadratic response, with the highest $\mathrm{PH}(47.71 \mathrm{~cm})$ obtained under the ESP of $27 \%$. Vasconcelos (1990), in studies with many cultivars of white cotton, observed that, on average, the highest $\mathrm{PH}$ values occurred at ESPs from 7 to $17 \%$, which indicates higher growth of the colored-fiber cotton cultivar 'BRS Topázio' than white cotton.

OM concentration also had a significant influence $(p<0.05)$ on plant height at 44 DAS and, according to the regression equation (Figure $3 \mathrm{C}$ ), the highest $\mathrm{PH}$ value $(46.31 \mathrm{~cm})$ was obtained when plants were subjected to a concentration of $12 \% \mathrm{OM}$.
As observed for $\mathrm{PH}$, the stem diameter of the cotton cultivar 'BRS Topázio' was significantly affected by the interaction (ESP $\times$ OM) at 10 DAS. According to the regression equations (Figure 4A), plants showed a linear response when subjected to 0 and $10 \% \mathrm{OM}$, and a quadratic response when subjected to $5 \%$; while there was no significant effect with $10 \%$ OM. Plants under $0 \%$ OM showed a decrease of about $3.28 \%$ in SD per unit increase in ESP. On the other hand, when plants were subjected to $5 \% \mathrm{OM}$, the highest $\mathrm{SD}$ value $(1.87 \mathrm{~mm})$ was obtained under an ESP of 33, i.e., cattle manure supply to the soil promoted higher growth of plants under high exchangeable sodium.

Figure 4. Stem diameter (SD) of the cotton cultivar 'BRS Topázio' as a function of the interaction between exchangeable sodium percentage (ESP) and the concentration of organic matter at 10 days after seeding (DAS; A), and as a function of ESP (B) and the concentration of organic matter at 44 DAS (C).

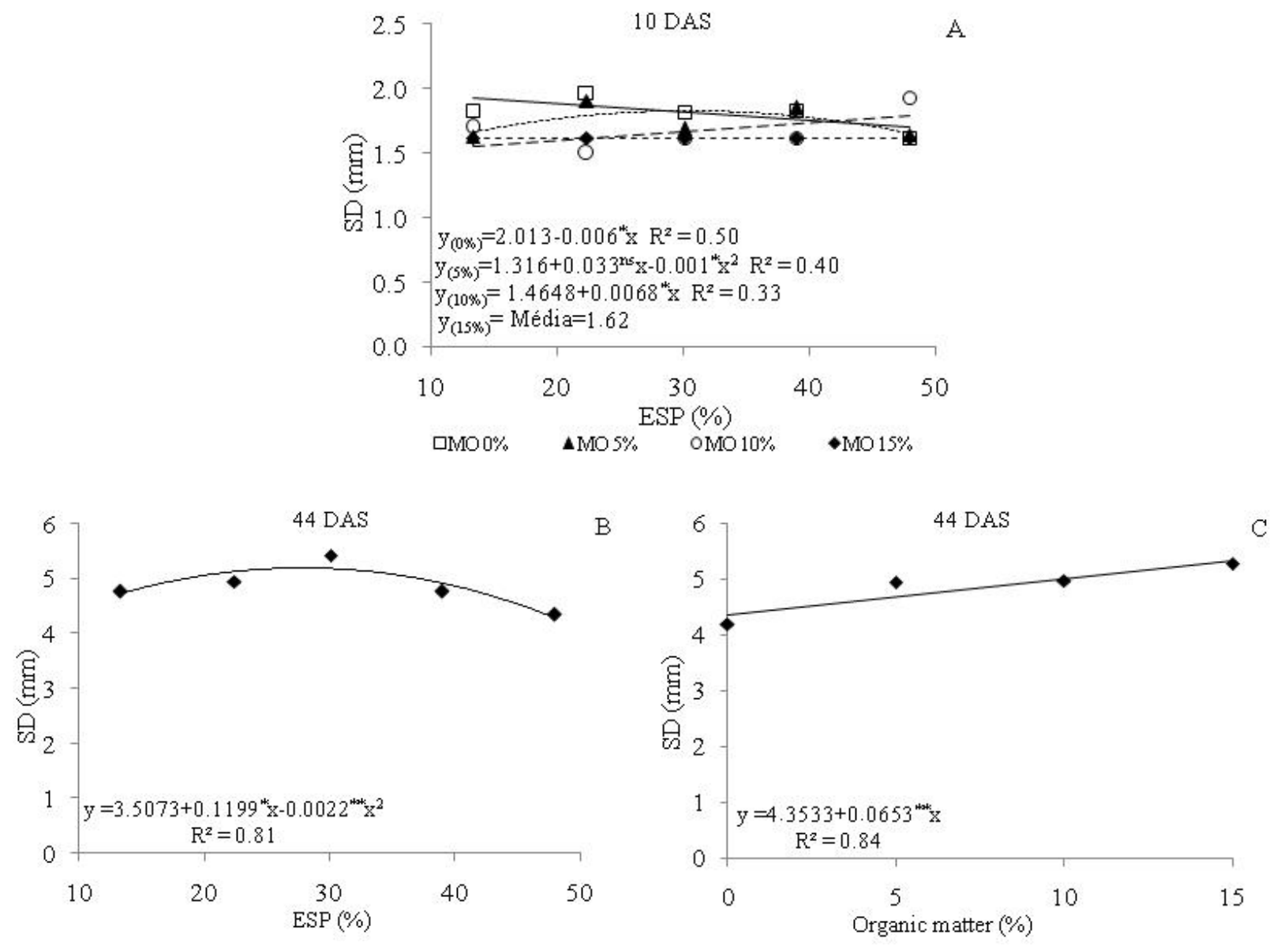


At 44 DAS, the ESP level showed a significant $(p<0.05)$ quadratic effect on stem diameter, with the highest value $(5.14 \mathrm{~mm})$ obtained when plants were subjected to soil with an ESP of 27, and the lowest one $(4.19 \mathrm{~mm})$ for an ESP of 48 (Figure 4B). For the same evaluation period, a significant response $(p<0.05)$ to OM concentration was observed, according to the regression equation (Figure 4C), with a linear increase of $1.5 \%$ in SD per unit increase of cattle manure, i.e., plants subjected to soil with $15 \%$ OM had an SD increase of about $22.5 \%$ over plants not receiving OM.
Cattle manure was of fundamental importance in the growth and development (NL, PH, and SD) of the cotton cultivar 'BRS Topázio' because organic matter, through ionic exchange, favors the supply of nutrients to plants and improves nutrient cycling and soil fertility (CANELLAS et al., 2000), factors that provide better nutritional conditions in the soil, contributing to plant growth and development.

According to the analysis of variance (Table $5)$, there was a significant effect of the ESP $\times$ OM interaction on cotton leaf area at 10 and 44 DAS, and a significant effect $(\mathrm{p}<0.01)$ of the isolated factors ESP and OM on the shoot fresh and dry matters of the cotton cultivar 'BRS Topázio' at 44 DAS.

Table 5. Summary of the analysis of variance for leaf area (LA) at 10 and 44 days after seeding (DAS) and shoot fresh matter (SFM) and shoot dry matter (SDM) of cotton at 44 DAS, cultivated in soil with different levels of exchangeable sodium percentage (ESP) and concentrations of organic matter (OM).

\begin{tabular}{|c|c|c|c|c|c|}
\hline \multirow{3}{*}{ Sources of variation } & \multirow{3}{*}{ DF } & \multicolumn{4}{|c|}{ Mean Square } \\
\hline & & \multicolumn{2}{|c|}{ LA } & \multirow{2}{*}{$\begin{array}{c}\text { SFM } \\
44\end{array}$} & \multirow{2}{*}{$\begin{array}{c}\text { SDM } \\
44 \\
\end{array}$} \\
\hline & & 10 & 44 & & \\
\hline $\begin{array}{l}\text { Exchangeable sodium } \\
\text { percentage (ESP) }\end{array}$ & 4 & $0.02^{*}$ & $202.27^{*}$ & $96.59^{* *}$ & $666.00^{* *}$ \\
\hline Linear Regression & 1 & $0.02^{*}$ & $22.34^{\text {ns }}$ & $31.05^{*}$ & $3.22^{*}$ \\
\hline Quadratic Regression & 1 & $0.05^{*}$ & $749.06^{*}$ & $313.48^{* *}$ & $19.44^{* *}$ \\
\hline Organic matter (OM) & 3 & $0.008^{*}$ & $548.05^{*}$ & $82.17^{* *}$ & $3.92^{* *}$ \\
\hline Linear Regression & 1 & $0.01^{*}$ & $1567.92^{*}$ & $160.95^{* *}$ & $10.35^{* *}$ \\
\hline Quadratic Regression & 1 & $0.00^{\mathrm{ns}}$ & $34.24^{\mathrm{ns}}$ & $58.45^{*}$ & $1.02^{\mathrm{ns}}$ \\
\hline Interaction $(\mathrm{ESP} \times \mathrm{OM})$ & 11 & $0.004^{* *}$ & $63.45^{* *}$ & $10.08^{\text {ns }}$ & $0.77^{\mathrm{ns}}$ \\
\hline Blocks & 2 & $0.002^{\mathrm{ns}}$ & $117.00^{* *}$ & $25.68^{\mathrm{ns}}$ & $1.13^{\text {ns }}$ \\
\hline CV $(\%)$ & & 34.67 & 24.73 & 25.05 & 33.62 \\
\hline
\end{tabular}

$\mathrm{ns}, * *$, and $*$ indicate, respectively, non-significant, significant at $\mathrm{p}<0.01$, and $\mathrm{p}<0.05$; DF -degrees of freedom; CV -coefficient of variation.

According to the regression equations for the interaction between the factors (Figure 5A), there was a quadratic response of LA when plants were subjected to OM concentrations of $0,5,10$, and $15 \%$, and the highest LA values at 10 DAS $(0.13$, $0.17,0.16$, and $0.15 \mathrm{~m}^{2}$ ) were obtained with ESPs of 13.6, 34.0, 35.0, and 25.0, respectively. At 44 DAS, LA was also significantly influenced $(p<0.01)$ by the interaction $(\mathrm{ESP} \times \mathrm{OM})$. According to the regression equations (Figure $5 \mathrm{~B}$ ) for $0 \% \mathrm{OM}$, adjusted to the linear model, LA decreased by $0.13 \mathrm{~m}^{2}$ for plants under an ESP of 48 compared to an ESP of 13.60. On the other hand, there was a quadratic response of LA when plants were subjected to 5, 10, and $15 \%$ OM, with the highest LA values $(0.21,0.20$, and $0.17 \mathrm{~m}^{2}$ ) obtained for ESPs of 36, 35, and 25, in the $0,5,10$, and $15 \%$ OM treatments, respectively.

As observed for the other previously mentioned variables, plants cultivated in sodic soils grew better with the addition of organic matter (cattle 
manure). In addition, the cotton cultivar 'BRS Topázio' cultivated in saline-sodic soil until the period preceding the flowering stage (44 DAS) tolerated a mean ESP level of $32 \%$, provided that well decomposed cattle manure was applied to the soil material. Cattle manure, used as organic matter, increases fertilizer use efficiency (NARDI et al., 2002), and the use of organic matter mitigates the effects of salts, mainly exchangeable sodium, as observed in this experiment.

Figure 5. Leaf area (LA) of the cotton cultivar 'BRS Topázio' as a function of the interaction between exchangeable sodium percentage (ESP) and the concentration of organic matter at 10 (A) and 44 (B) days after seeding (DAS).

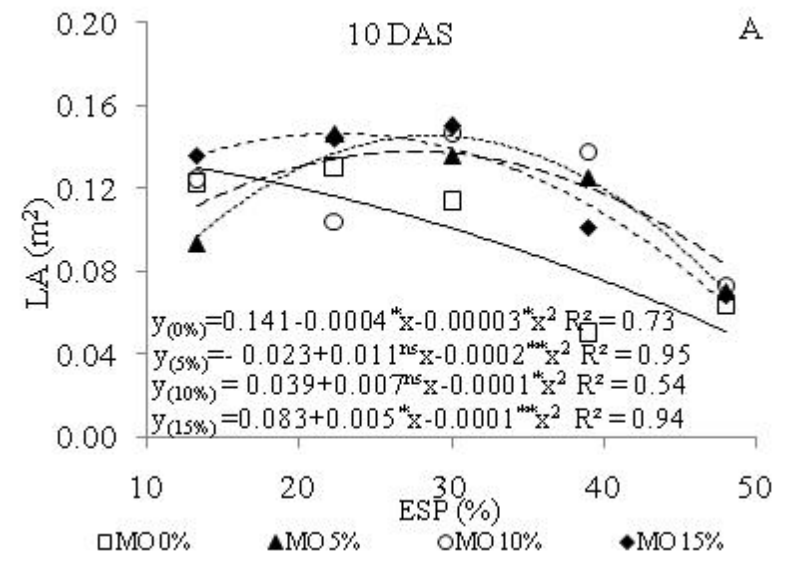

The shoot fresh and dry matters of cotton at 44 DAS were significantly affected by the ESP levels and, according to the regression equations, the best adjustment was the quadratic one, indicating that the highest SFM (14.49 g; Figure 6A) and SDM (3.26 g; Figure 7A) were obtained in plants cultivated in soil with an ESP of 30 . In addition, the lowest values of SFM (8.03 g) and SDM (1.60 g)

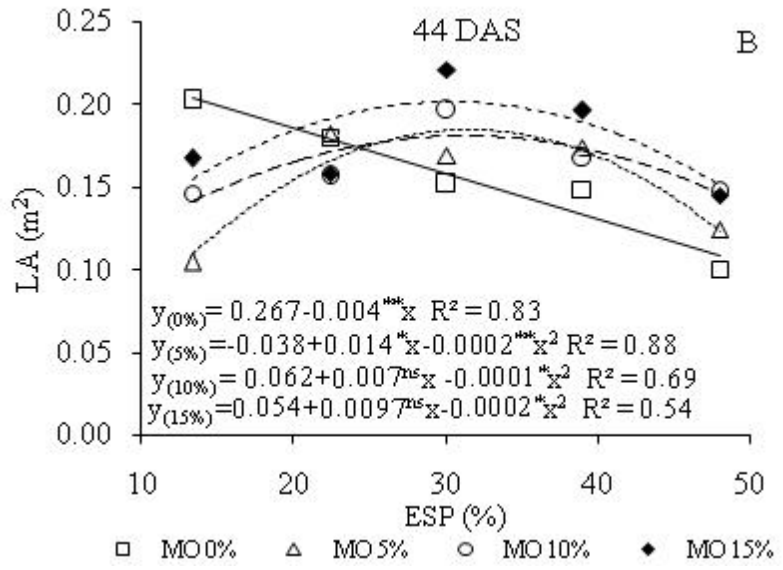

were obtained under an ESP of 48. According to the analysis of the different growth variables $(\mathrm{NL}, \mathrm{PH}$, SD, LA, SFM, and SDM), the cotton cultivar 'BRS Topázio', cultivated in a saline-sodic soil until the period preceding the flowering stage (44 DAS), was tolerant to ESP levels of up to 30, the point at which the crop showed the best results.

Figure 6. Shoot fresh matter (SFM) of the cotton cultivar 'BRS Topázio' as a function of the exchangeable sodium percentage (ESP; A) and the concentration of organic matter (B) at 44 days after seeding (DAS).
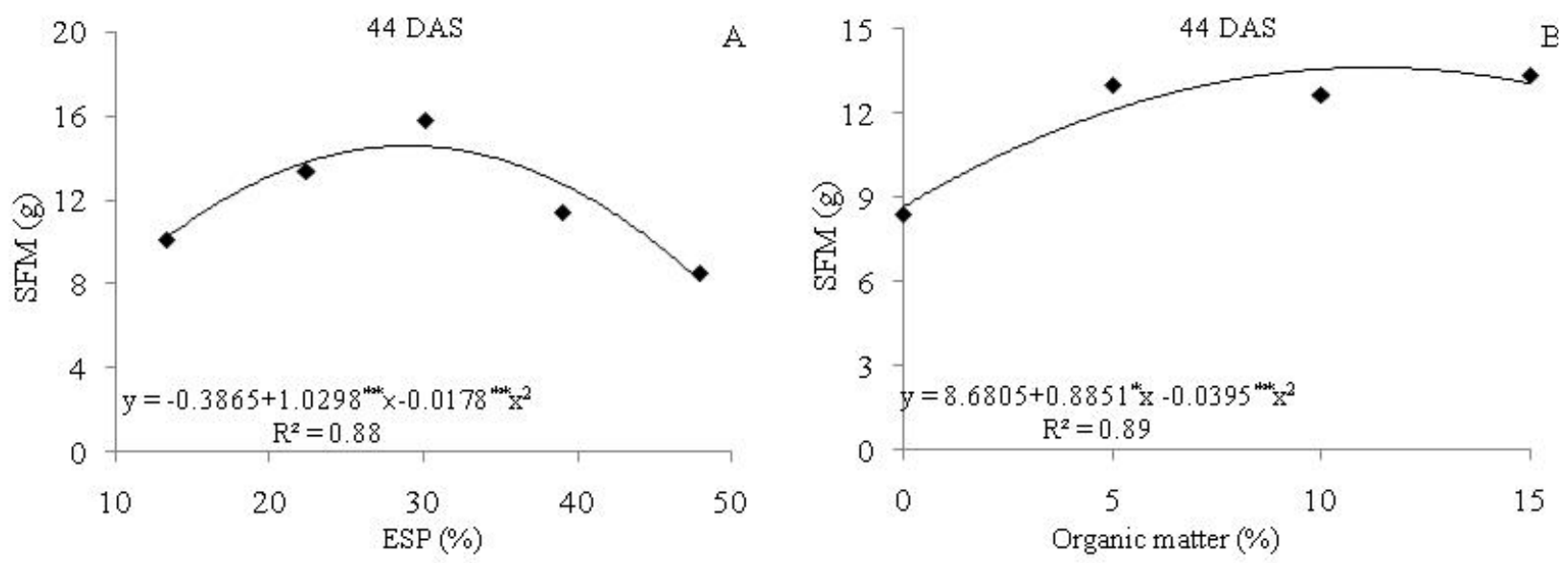
As for the OM concentration, according to the regression equation (Figure 6B), 11\% OM promoted the highest SFM (13.63 g), while 0\% OM produced the lowest ( $8.68 \mathrm{~g}$ ). Based on the regression equation (Figure 7B), there was a linear effect on SDM, with an increment of $3.64 \%$ per unit increase of OM, i.e., an increase of $54.6 \%$ in SDM of plants in $15 \% \mathrm{OM}$ compared to treatment of $0 \% \mathrm{OM}$. The application of well decomposed cattle manure and/or another type of organic matter is essential in saline-sodic soils, since these substances improve soil structure and nutrient supply, especially nitrogen and phosphorus (MENEZES; SALCEDO, 2007); and lead to higher aeration and water availability to plants.

Figure 7. Shoot dry matter (SDM) of the cotton cultivar 'BRS Topázio' as a function of the exchangeable sodium percentage (ESP; A) and the concentration of organic matter (B) at 44 days after seeding (DAS).

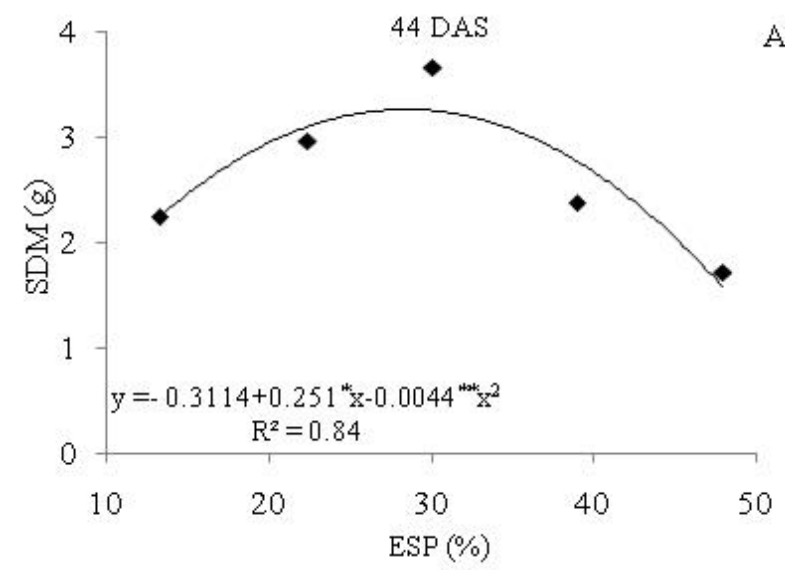

\section{Conclusions}

Soils with an exchangeable sodium percentage of 13.3-48.0 do not affect the emergence and number of leaves of the cotton cultivar 'BRS Topázio' at 10 days after seeding;

During the period preceding the cotton flowering stage, an exchangeable sodium percentage of 27-30 promotes greater plant height, stem diameter, and shoot fresh and dry matter;

The application of organic matter increases the emergence percentage and emergence speed index and, at 44 days after seeding, plant height, stem diameter, and shoot fresh and dry matters in cotton plants;

Increasing the concentration of organic matter mitigates the effects up to $30 \%$ exchangeable sodium percentage on the number of leaves, plant height, stem diameter, and leaf area of cotton at 10 days

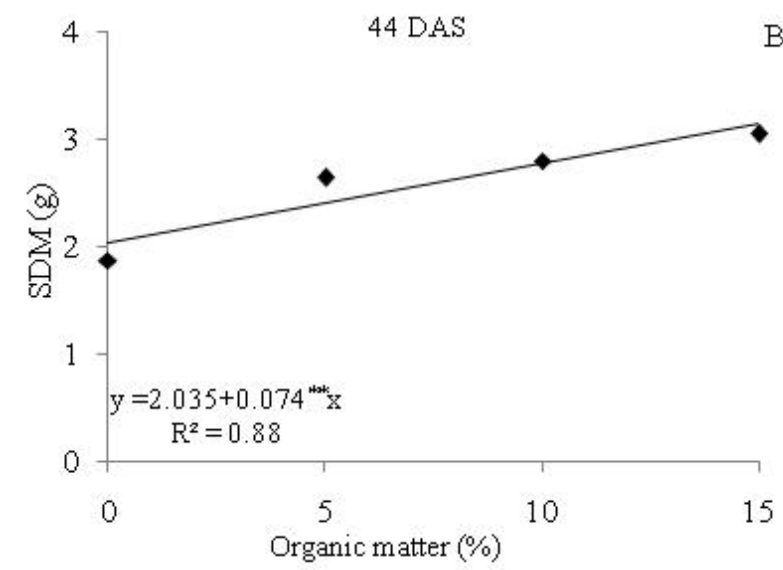

after seeding, and the effects on number of leaves and leaf area up to 28.5 and $34.0 \%$, respectively, at 44 days after seeding.

\section{References}

BARROS, M. de F. C.; FONTES, M. P. F.; ALVAREZ, V. H.; RUIZ, H. A. Aplicação de gesso e calcário na recuperação de solos salino-sódicos do Estado de Pernambuco. Revista Brasileira de Engenharia Agrícola Ambiental, Campina Grande, v. 9, n. 3, p. 320-326, 2005.

BELTRÃO, N. E. M.; AZEVEDO, D. M. P. de. O agronegócio do algodão no Brasil. 2. ed. rev. ampl. Brasília: Embrapa Informação Tecnológica, 2008. 1309 p.

CAMPOS, V. B.; CAVALCANTE, L. F.; RODOLFO JÚNIOR, F.; SOUSA, G. G.; MOTA, J. K. M. Crescimento inicial da mamoneira submetido à irrigação com água salina e biofertilizante bovino. Magistra, Cruz das Almas, v. 21, n. 1, p. 40-47, 2009.

CANELlAS, L. P.; SANTOS, G. A.; RUMJANEK, V. M.; MORAES, A. A.; GURIDI, F. Avaliação de características de ácidos húmicos de resíduos sólidos 
urbanos I. Métodos espectroscópicos (IV, UV e RMN $\left.{ }^{13} \mathrm{C}\right)$ e microscopia eletrônica de varredura. Revista Brasileira de Ciência do Solo, Viçosa, MG, v. 24, n. 4, p. 741-750, 2000.

CLAESSEN, M. E. C. (Org.). Manual de métodos de análise de solo. 2. ed. rev. atual. Rio de Janeiro: EmbrapaCNPS, 1997. 212 p. (Documentos, 1).

DOORENBOS, J.; KASSAM, A. H. Efeito da água no rendimento das culturas. Campina Grande: UFPB, 1994. $218 \mathrm{p}$.

FREIRE, M. B. G. S.; FREIRE, F. J. Fertilidade do solo e seu manejo em solos afetados por sais. In: NOVAIS, R. F.; ALAREZ, V. V. H.; BARROS, N. F.; FONTES, R. L. F.; CANTARUTTI, R. B.; NEVES, J. C. L. (Ed.). Fertilidade do solo. Viçosa, MG: SBCS, 2007. cap. 16, p. 929-954.

FERREIRA, D. F. SISVAR 4,6 - programa de análise estatística. Lavras: Universidade Federal de Lavras, 2003. 1 CD-ROM.

GHEYI, H. R. Problemas de salinidade na agricultura irrigada. In: OLIVEIRA, T. S. de; ASSIS JÚNIOR, R. N.; ROMERO, R. E.; SILVA, J. R. C. (Org.). Agricultura, sustentabilidade e o semiárido. Viçosa, MG: Folha de Viçosa/SBCS, 2000. v. 1, p. 329-346.

GRIMES, D. W.; CARTER, L. M. A linear rule for direct non destructive leaf area measurements. Agronomy Journal, Madison, v. 61, n. 3, p. 477-479, 1969.

LEAL, I. G.; ACCIOLY, A. M. de A.; NASCIMENTO, C. W. A. do; FREIRE, M. B. G. dos S.; MONTENEGRO, A. A. de A.; FERREIRA, F. de L. Fitorremediação de solo salino sódico por Atriplex nummularia e gesso de jazida. Revista Brasileira de Ciência do Solo, Viçosa, MG, v. 32, n. 3, p. 1065-1072, 2008.

LEITE, E. M.; CAVALCANTE, L. F.; DINIZ, A. A.; SANTOS, R. V. dos; ALVES, G. da S.; CAVALCANTE, I. H. L. Correção da sodicidade de dois solos irrigados em resposta à aplicação de gesso agrícola. Irriga, Botucatu, v. 12, n. 2, p. 168-176, 2007.

MALAVOLTA, E. Manual de nutrição mineral de plantas. Piracicaba: Ceres, 2006. 631 p.

MAAS, E. V.; HOFFMAN, G. J. Crop salt tolerance - current assessment. Journal of the Irrigation and Drainage Engineering, New York, v. 103, n. 2, p. 115134, 1977.

MELO, R. M.; BARROS, M. de F. C.; SANTOS, P. M. dos; ROLIM, M. M. Correção de solos salino-sódicos pela aplicação de gesso mineral. Revista Brasileira de Engenharia Agrícola Ambiental, Campina Grande, v. 12, n. 4, p. 376-380, 2008.
MENEZES, R. S. C.; SALCEDO, I. H. Mineralização de $\mathrm{N}$ após incorporação de adubos orgânicos em um Neossolo Regolítico cultivado com milho. Revista Brasileira de Engenharia Agrícola e Ambiental, Campina Grande, v. 11, n. 4, p. 361-367, 2007.

MUNNS, R.; JAMES, R. A.; LAUCHLI, A. Approaches to increasing the salt tolerance of wheat and other cereals. Journal of Experimental Botany, Oxford, v. 57, n. 5, p. 1025-1043, 2006.

NARDI, S.; PIZZEGHELLO, D.; MUSCOLO, A.; VIANELLO, A. Physiological effects of humic substance on higher plants. Soil Biology \& Biochemistry, Exeter, v. 34, n. 11, p. 1527-1536, 2002.

NOVAIS, R. F.; NEVES J. C. L.; BARROS, N. F. Ensaio em ambiente controlado. In: OLIVEIRA, A. J. (Ed.). Métodos de pesquisa em fertilidade do solo. Brasília: Embrapa-SEA, 1991. p. 189-253.

PIZZARRO, F. Drenaje agrícola y recuperación de suelos salinos. Madrid: Editorial Agrícola Española, 1978. $521 \mathrm{p}$.

SANTOS, M. de F. G.; OLIVEIRA, F. A. de; CAVALCANTE, L. F.; MEDEIROS, J. F. de; SOUZA, C. C. de. Solo sódico tratado com gesso agrícola, composto de lixo urbano e vinhaça. Revista Brasileira de Engenharia Agrícola e Ambiental, Campina Grande, v. 9, n. 3, p. 307-313, 2005.

SILVA, A. B. F.; FERNANDES, P. D.; GHEYI. BLANCO, F. F. Growth and yield of guava irrigated with saline water and addition of farmyard manure. Revista Brasileira de Ciências Agrárias, Recife, v. 3, n. 4, p. 354359, 2008.

SOUSA, F. Q. de; ARAÚJO, J. L.; SILVA, A. P. da; PEREIRA, F. H. F.; SANTOS, R. V. dos; LIMA, G. S. de. Crescimento e respostas fisiológicas de espécies arbóreas em solo salinizado tratado com corretivos. Revista Brasileira de Engenharia Agrícola Ambiental, Campina Grande, v. 16, n. 2, p. 173-181, 2012.

VASCONCELOS, M. F. de. Comportamento de cultivares do algodoeiro herbáceo sob diferentes percentagens de sódio trocável. Campina Grande: Universidade Federal da Paraíba. 1990. 68 p.

VIEIRA, R. D.; CARVALHO, N. M. Teste de vigor em sementes. Jaboticabal: FUNEP/UNESP-FCAVJ, 1994. $164 \mathrm{p}$.

VITAL,A. de F. M.; SANTOS, R. V. dos; CAVALCANTE, L. F.; SOUTO, J. S. Comportamento de atributos químicos de um solo salino-sódico tratado com gesso e fósforo. Revista Brasileira de Engenharia Agrícola Ambiental, Campina Grande, v. 19, n. 1, p. 30-36, 2005. 
